\title{
The First U.S. Quantitative Easing: The 1930s
}

\author{
Richard G. Anderson, Vice President and Economist*
}

$\mathrm{T}$ he term "quantitative easing" became popular jargon in 2009. After setting the target for the federal funds rate at a range of zero to 25 basis points on December 28, 2008, the Federal Open Market Committee announced its intent to purchase up to approximately $\$ 1.7$ trillion of agency debt, agency-guaranteed mortgage-backed securities, and Treasury securities. The Treasury collaborated, buying for its own account approximately $\$ 220$ billion in agency mortgage-backed securities during 2009. This policy was labeled quantitative easing.

Few analysts recall, however, that this is the second, not the first, quantitative easing by U.S. monetary authorities. ${ }^{1}$ During 1932, with congressional support, the Fed purchased approximately $\$ 1$ billion in Treasury securities (half, however, was offset by a decrease in Treasury bills discounted at the Reserve Banks). At the end of 1932, short-term market rates hovered at 50 basis points or less. Quantitative easing continued during 1933-36. In early April 1933, Congress sought to prod the Fed into further action by passing legislation that (i) permitted the Fed to purchase up to $\$ 3$ billion in securities directly from the Treasury (direct purchases were not typically permitted) and, if the Fed did not, (ii) also authorized President Roosevelt to issue up to $\$ 3$ billion in currency. ${ }^{2}$ The Fed began to purchase securities in the open market in April at the modest pace of $\$ 50$ million per week.

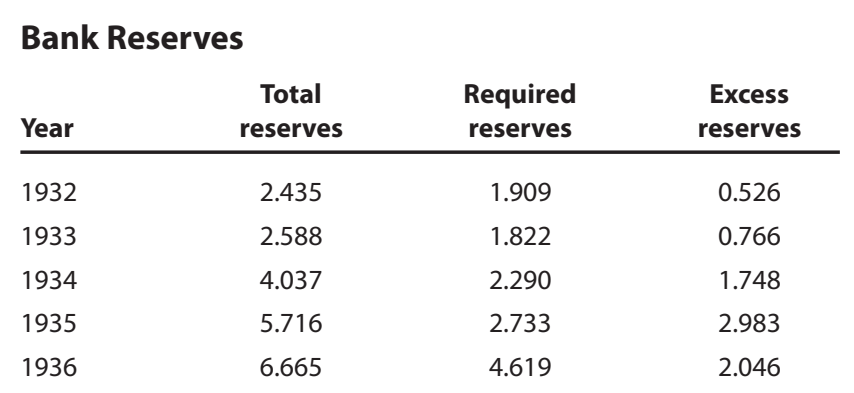

NOTE: Data are December figures, in billions of dollars. SOURCE: Banking and Monetary Statistics 1914-1941, p. 396.
During the summer of 1933, as excess reserves reached $\$ 500$ million, Fed officials' reluctance increased. Nevertheless, as Meltzer (2003) reports, President Roosevelt wished purchases to continue. On October 10, 1933, hoping to avoid a political confrontation, Fed officials decided to continue purchases. Yet, on October 12, these officials unanimously approved a statement to the president noting that (i) the System's holdings of government securities exceeded $\$ 2$ billion, (ii) bank reserves had reached a record high, and (iii) short-term money rates had dipped to record lows. They halted purchases in November 1933. Quantitative easing did not end there, however: It instead shifted to the Treasury and the White House through gold purchases.

\section{During 1932, with congressional support, the Fed purchased approximately $\$ 1$ billion in Treasury securities.}

The Fed's reluctance could be overcome with gold. President Roosevelt controlled both the nation's gold stock and monetary policy, so long as the Federal Reserve remained inactive. The president's most effective tool was the Gold Reserve Act, passed January 30, 1934, which raised the value of gold from $\$ 20.67$ to $\$ 35$ per ounce. The mechanism by which the Treasury gained control was elegantly simple. On August 28, 1933, Roosevelt called all outstanding domestic gold into the Federal Reserve Banks; on January 30, ownership was transferred, before revaluation, to the Treasury from the Federal Reserve Banks in exchange for (paper) gold certificates. When gold's price increased to $\$ 35$ per ounce from $\$ 20.67$, the Treasury realized a windfall profit of more than $\$ 2$ billion. The Treasury, Meltzer (2003) reports, began purchasing gold "immediately" via the issuance of additional gold certificates-bank reserves and the monetary base expanded when the gold certificates later were received by the Federal Reserve Banks. During 1934-36, the Treasury purchased $\$ 4$ billion in gold in international 
markets, sharply increasing bank reserves and the monetary base. The effect on bank reserves is displayed in the table. In 1936, as today, concern arose regarding inflation. Then, the Fed's exit strategy was higher statutory reserve requirements, infeasible today. Today, the Fed's exit strategy includes increasing the remuneration rate on deposits at the Fed, offering banks term deposits at the Fed, and the use of repurchase agreements. ${ }^{3}$
1 This section draws on Meltzer, Alan H. A History of the Federal Reserve, Volume 1: 1913-1951. Chicago: University of Chicago Press, 2003.

2 The legislation also permitted the president to devalue the dollar relative to gold by up to 50 percent. President Roosevelt signed this legislation and the same day ordered all domestically held gold in the United States be sold to the Treasury (including gold held by the Federal Reserve Banks).

${ }^{3}$ See Bernanke, Ben. "Federal Reserve's Exit Strategy." Testimony before the Committee on Financial Services, U.S. House of Representatives, Washington, DC, March 25, 2010.

${ }^{*} \mathrm{He}$ is also a visiting scholar at the School of Business, Aston University, Birmingham, U.K. 